\title{
Seasonality and environmental control of freshwater SAR11 (LD12) in a temperate lake (Lake Erken, Sweden)
}

\author{
Friederike Heinrich, Alexander Eiler, Stefan Bertilsson*
}

Department of Ecology and Genetics, Limnology, and Science for Life Laboratories, Uppsala University, 75236 Uppsala, Sweden

\begin{abstract}
THE SAR11 clade is ubiquitous and abundant in planktonic environments. In freshwater lakes, the clade is represented by tribe LD12 which is phylogenetically distinct from the marine SAR11. We studied the ecology of LD12 in a temperate dimictic lake (Lake Erken, Sweden), by analyzing its seasonal dynamics with quantitative PCR, CARD-FISH and 454 pyrosequencing of the 16S rRNA gene. Results showed that LD12 can be as numerous in freshwater bacterioplankton as their marine SAR11 siblings. They exhibited strong seasonality and made up from 1.8 to $40 \%$ of the total bacterial 16S rRNA pool (mean $14 \%$ ) with pronounced peaks in summer and late fall. Except in spring, LD12 was the dominant Alphaproteobacteria, contributing on average $72 \%$ of the $16 \mathrm{~S}$ rRNA within this class. The LD12 population was dominated by a single persistent ribotype, suggesting low local divergence, at least at the phylogenetic resolution accessed with rRNA genes. The relative abundance of LD12 was positively correlated to nutrient concentrations (phosphate, ammonia, nitrate, and silica) and water transparency whereas the relative abundance was lower during periods characterized by high phytoplankton biomass. Based on these observations we propose that LD12 are poor competitors during periods of high phytoplankton productivity and associated release of labile organic compounds, but thrive when availability of inorganic nutrients is high. Similar to the marine SAR11 sibling group, local LD12 populations appear to respond in contrasting ways to nutrient availability in different lakes, pointing to either ecological divergence within the tribe or variations in the interplay between environmental driver variables.
\end{abstract}

KEY WORDS: LD12 · Freshwater SAR11 · Alphaproteobacteria · Seasonal dynamics · Quantitative PCR $\cdot 454$ Pyrosequencing $\cdot$ CARD-FISH $\cdot$ 16S rRNA

Resale or republication not permitted without written consent of the publisher

\section{INTRODUCTION}

It has long been recognized that the SAR11 clade within Alphaproteobacteria is one of the most widely distributed bacterioplankton groups in marine environments, contributing up to $50 \%$ of the marine bacterial community (Morris et al. 2002, Alonso-Sáez et al. 2007, Carlson et al. 2009, Eiler et al. 2009). Application of cultivation-independent molecular tools to study the diversity and composition of bacterial communities in freshwater ecosystems (e.g. 16S rRNA cloning and sequencing) has revealed a phylogenetically distinct sibling group from marine SAR11, called LD12 (Bahr et al. 1996, Zwart et al. 1998). PCRbased 16S rRNA surveys have detected LD12 in multiple distributed freshwater ecosystems ranging from Toolik Lake in Alaska to Lake Soyang in Korea (Bahr et al. 1996, Glöckner et al. 2000, Zwart et al. 2002). In a recent review of globally distributed freshwater lakes, it was shown that rRNA gene sequences of the tribe LD12 were present in more than half of the 47 bacterial 16S rRNA clone libraries analyzed from 
these pelagic systems (Newton et al. 2011). In the hierarchical naming structure proposed by Newton et al. (2011), a tribe is defined as consistent group of sequences clustering with a $97 \%$ sequence identity within a monophyletic branch; at least 2 sequences detected in different locations are required to form a tribe.

Despite its cosmopolitan distribution in lakes, our knowledge about the natural history and ecology of LD12 is still incomplete and mainly stems from a few studies that have used PCR-based clone library screening and community fingerprinting, giving results that are not necessarily quantitative (e.g. Methé \& Zehr 1999, Lindström \& Leskinen 2002, Zwart et al. 2002, Eiler \& Bertilsson 2004, Lindström et al. 2005).

A recent study based on fluorescence in situ hybridization demonstrated for the first time the quantitative importance of LD12 in different European lakes (Salcher et al. 2011a). Based on morphological information and substrate-tracking microautoradiography, it was described as an ultramicrobacterium, exhibiting a heterotrophic lifestyle with slow but efficient uptake of even low levels of organic substrates (Salcher et al. 2011a). Originally considered to thrive mainly in oligotrophic waters (Giovannoni et al. 1990, Morris et al. 2002, Giovannoni \& Sting 2005, Joint 2008) recent metagenomic surveys have revealed high marine SAR11 abundances also in more productive coastal waters (e.g. Rusch et al. 2007). Analogously, LD12 sequences have been detected in lakes of contrasting productivity including eutrophic (Zwart et al. 1998, 2002, Eiler \& Bertilsson 2004, Salcher et al. 2011a), mesotrophic (Hiorns et al. 1997, Lindström et al. 2005, Salcher et al. 2011a), and oligotrophic systems (Bahr et al. 1996, Urbach et al. 2001, Lindström et al. 2005, Salcher et al. 2011a). Furthermore, a recent comparison of bacterioplankton community composition in globally distributed lakes suggests that LD12 appears to be more common in lakes with high $\mathrm{pH}$ and low dissolved organic carbon:total phosphorus (DOC:TP) ratios, the latter being an indicator of lake trophic status (Newton et al. 2011). Such between-system comparisons are valuable, but quantitative measurements under variable environmental conditions in a well-described system can provide more highly resolved information on the physiochemical boundaries and ecological requirements of single bacterial groups, such as LD12. Compared to spatial surveys that include multiple lakes, studies of temporal dynamics within a single system are minimally influenced by dispersal limitations and instead emphasize ecological processes acting on the local scale. Addition- ally, the added complexity in interpreting ecological traits for a population caused by allopatric diversification is likely less severe for such temporal studies.

In the present study we completed a quantitative survey of LD12 dynamics in a well-studied temperate freshwater lake. Our broad aims were (1) to assess whether or not this freshwater tribe can be as numerous in freshwater bacterioplankton communities as its marine sister group is in oceanic waters, (2) to describe whether the abundance of LD12 is temporally dynamic, and (3) to identify the potential mechanisms and variables causing observed changes in their abundance. Annual dynamics of LD12 diversity within this clade were also examined. The combined use of quantitative PCR (qPCR), parallel 454 pyrosequencing targeting bacterial 16S rRNA genes and CARD-FISH (catalyzed reporter deposition fluorescence in situ hybridization) revealed not only dynamic shifts in abundance of LD12, but also putative linkages to other bacterial community members.

\section{MATERIALS AND METHODS}

\section{Sampling}

Lake Erken $\left(59^{\circ} 51^{\prime} \mathrm{N}, 18^{\circ} 36^{\prime} \mathrm{E}\right)$ is a medium sized $\left(23.7 \mathrm{~km}^{2}\right.$, average depth $\left.9 \mathrm{~m}\right)$ mesotrophic to moderately eutrophic lake located near Stockholm in southeastern Sweden. The residence time of this dimictic lake is approximately $6.6 \mathrm{yr}$ suggesting that internal processes are important in determining lake water characteristics. This lake has been monitored intensively since 1993 and integrated water samples are continuously sampled and analyzed on a monthly (October to March) or weekly (April to September) basis (Pettersson et al. 2003). Lake Erken is characterized by neutral to slightly alkaline $\mathrm{pH}(\sim 8)$, and conductivity $\sim 27 \mathrm{mS}$ (Pettersson 1990). The lake has 12 small inlets and is influenced by surrounding farmland that can cause episodic nutrient inputs to the lake. In 2008, lake water samples were collected weekly to monthly (32 occasions), including during the spring bloom, summer stratification, and period of ice coverage. Water samples were collected $700 \mathrm{~m}$ from the shoreline at the deepest point of the lake. Pooled water samples consisting of equal volumes of discrete water samples collected at $1 \mathrm{~m}$ intervals were first combined and separate aliquots were then either filtered for DNA extraction or used to analyze water characteristics. The integrated water samples were either from the entire $20 \mathrm{~m}$ water column or from different water masses during the period of 
summer stratification (epilimnion and hypolimnion). In total 22 depth-integrated samples from the entire water column, and 10 epilimnetic and 10 hypolimnetic water samples were analyzed.

\section{Chemical analyses and bacterial abundance}

Environmental variables were analyzed at the Norr Malma Field Station using methods developed and maintained by the Swedish and International Standards Organization (SS-ISO). Chemical variables analyzed included $\mathrm{pH}$, conductivity, nitrate, nitrite, water color, alkalinity, turbidity, suspended matter, phosphate, ammonium, total and particulate phosphorus and nitrogen, chlorophyll $a$, biological oxygen demand, absorbance, and silica (see Table S1 in the Supplement at www.int-res.com/articles/suppl/ a070p033_supp.pdf). Additionally, temperature and oxygen concentrations were analyzed at each depth using a portable Oxi 340i oxygen meter equipped with a Celox 325-20WTW probe.

Samples for bacterial abundance were preserved with ethanol (50\% final concentration) and stored at $-20^{\circ} \mathrm{C}$ (Sekar et al. 2003). During analysis, subsamples were diluted 1:10 with borax buffered $0.2 \mu \mathrm{m}$ filtered autoclaved tap water. Cell counts were performed using flow cytometry (CyFlow ${ }^{\circledR}$ Space, Partec) with a final Syto13 concentration of $1.25 \mu \mathrm{M}$ (del Giorgio et al. 1996). A comparison of samples preserved with either $2 \%$ formaldehyde or ethanol produced nearly identical results for cell concentrations ranging from $10^{4}$ to $10^{6}$ cells $\mathrm{ml}^{-1}\left(\mathrm{R}^{2}=0.99\right.$, slope $=1.07, \mathrm{p}<0.001, \mathrm{n}=15)$. The species composition of phytoplankton was determined microscopically (Leitz Wetzlar, Diavert).

\section{Nucleic acid extraction}

Planktonic cells from 0.51 of lake water were collected on $0.2 \mu \mathrm{m}$ Supor ${ }^{\circledR}-200,47 \mathrm{~mm}$ diameter membrane filters (Pall Corporation). Filters were placed into sterile cryogenic vials (Nalgene) and stored frozen. DNA was extracted by bead-beating and solid phase extraction using the MO BIO UltraClean Soil DNA Isolation Kit according to the manufacturer's instructions. The quality and amount of extracted DNA was determined by agarose-gel electrophoresis ( $1 \%$ agarose, $0.5 \times$ tris-borate-EDTA) followed by detection with ethidium bromide staining, UV-transillumination, computer-aided image analysis (Gel-Pro Analyzer version 3.1. Media Cybernet- ics) and compared against a High Mass DNA Ladder (Invitrogen). Extracts containing between 1 and 20 ng DNA $\mu l^{-1}$ were used for qPCR.

\section{Quantitative PCR}

A plasmid with a 16S rRNA insert from freshwater SAR11/LD12 was extracted from clone AY509387 (Eiler \& Bertilsson 2004) for use as a positive control and as a standard for the estimation of $16 \mathrm{~S}$ rRNA gene copies for both freshwater SAR11 and for the combined pool of bacterial 16S rRNA genes. Plasmids were isolated using the QIAprep Spin Miniprep Kit (Qiagen) and subsequently linearized by a $4 \mathrm{~h}$ digestion at $37^{\circ} \mathrm{C}$ with Pst I endonuclease (NEB). Linearized plasmids were sized and quantified by gel electrophoresis (1.5\% agarose). The product showed the expected size (5458 bp) and was thus excised from the gel and purified with a Qiagen Gel Extraction Kit. DNA concentration was quantified by fluorescence using a Picogreen assay (Invitrogen) in an Ultra 384 fluorescence microplate reader (Tecan).

qPCR amplification was performed using a Chromo-4 real-time PCR system (Biorad) by parallel use of the bacterial primer pair 341F-805R (Herlemann et al. 2011) and the LD12-specific primer pair S11F-577F and S11F-732R (Table 1). Primers for the LD12 specific qPCR were designed using the Green Genes database (http://greengenes. lbl.gov). The ARB probe tool was used and first quality control by matching probes was conducted using also the in-house freshwater bacterial 16S rRNA database (Newton et al. 2011). In a second step primers were subjected to standard nucleotide blast against the $\mathrm{nr} / \mathrm{nt}$ database in NCBI. Primers were perfectly complementary to all 16S rRNA sequences of LD12 and had at the 3' end 2 or more mismatches with other bacteria including marine SAR11. Annealing temperatures were first estimated using the Oligo Calc (Oligonucleotide Properties Calculator; www.basic.northwestern.edu/biotools/ oligocalc.html). Real-time PCR assays were then optimized for the primer set along an annealing temperature gradient. Next, the specificity of the assay was investigated by testing the primer set with non-target template against numerous marine SAR11 isolates (HIMB114, HIMB95, HIMB125, HIMB104, HIMB58, HIMB83, HTCC1002; Grote et al. 2012) at concentrations of at least 1000 genomes per reaction. This corresponds to a concentration of at least $1 \times 10^{5}$ cells $\mathrm{ml}^{-1}$ for detection from field samples, comparable to the maximum reported abundance of natural populations of SAR11 (Eiler et al. 2009, Morris et al. 2002). 
Table 1. Oligonucleotides used for PCR amplification, cloning, sequencing, qPCR and 454 pyrosequencing of 16S rRNA, for study of seasonal dynamics of LD12 in a temperate dimictic lake

\begin{tabular}{|llcc|}
\hline Primer & Sequence 5' to 3' & E.coli position & Source \\
\hline $27 \mathrm{~F}$ & AGA GTT TGA TCM TGG CTC AG & 8 & Lane (1991) \\
$519 \mathrm{R}$ & GWA TTA CCG CGG CKG CTG & 519 & Lane (1991) \\
S11F-577F & GCG CGT AGG CCG TTG AGT TA & 577 & Present study \\
S11F-732R & CAG TGT TGA TCC AGA AAG CC & 732 & Present study \\
$341 \mathrm{~F}+$ Adaptor B & CCT ACG GGN GGC WGC AG & 341 & Herlemann et al. (2011) \\
& CCT ATC CCC TGT GTG CCT TGG CAG TCT CAG & & Herlemann et al. (2011) \\
805R + Adaptor A & GAC TAC HVG GGT ATC TAA TCC & 805 & \\
\hline
\end{tabular}

The amplification regime chosen for bacterial $16 \mathrm{~S}$ rRNA genes used primer concentrations of $0.45 \mathrm{mM}$ for both primers and $59^{\circ} \mathrm{C}$ annealing temperature. Conditions for LD12-specific amplification of $16 \mathrm{~S}$ rRNA genes were $0.1 \mathrm{mM}$ for the forward primer and $0.25 \mathrm{mM}$ for the reverse primer, with a $53^{\circ} \mathrm{C}$ annealing temperature. PCR reactions $(20 \mu \mathrm{l})$ contained $1 \times$ iQ SYBR Green Supermix, 0.4 nM BSA (NEB), either of the 2 primer-pairs (Table 1) and between 10 and $70 \mathrm{ng}$ of template DNA. All amplification reactions used an initial 5 min denaturation at $95^{\circ} \mathrm{C}$ followed by 40 cycles of $40 \mathrm{~s}$ denaturation at $95^{\circ} \mathrm{C}, 40 \mathrm{~s}$ annealing at the respective annealing temperature and $60 \mathrm{~s}$ elongation at $72^{\circ} \mathrm{C}$. All PCR reactions were finalized with a 7 min elongation at $72^{\circ} \mathrm{C}$ and a melting curve analysis; qPCR standards and sample reactions were performed in triplicate.

Standard reactions with linearized plasmid containing between 10 and $10^{6}$ gene copies displayed a linear response and amplification efficiencies of $86 \%$ for bacterial primers and $96 \%$ for the LD12 primers (Table S2 in the Supplement).

The detection of a single peak in the melting curve after the amplification of both samples and standards indicated high specificity. Performing inhibition tests showed no amplification inhibition by the samples (Table S2). No amplification was detected in negative controls or for the control LD12-specific assays containing marine SAR11 strains HTCC1002, HTCC1062, HTCC7211 and HIMB114 (Grote et al. 2012). We estimated the abundance of LD12 normalized to the abundance of total bacterial 16S rRNA.

Preliminary inspection of 10 freshwater LD12 single amplified genomes (S. Bertilsson unpubl. data) suggest that LD12 genomes are as streamlined as the marine SAR11, Pelagibacter ubique (Giovannoni et al. 2005a). Hence estimates of LD12 abundance are likely to be conservative. To further verify the specificity of the LD12-specific PCR, a Lake Erken bacterioplankton sample (epilimnic, July 15) was amplified for subsequent cloning and sequencing. Triplicate $20 \mu \mathrm{l}$ PCR reactions were amplified using the thermocycling program outlined above. Each reaction contained 1 to $5 \mathrm{ng}$ of target DNA, PCR buffer $(10 \mathrm{mM}$ tris- $\mathrm{HCl}, \mathrm{pH}$ 9, $50 \mathrm{mM} \mathrm{KCl}, 0.1 \%$ Triton $\mathrm{X}-100$ and $\left.2 \mathrm{mM} \mathrm{MgCl}_{2}\right), 0.25 \mathrm{U}$ recombinant taq DNA polymerase (Invitrogen), $0.2 \mathrm{mM}$ dNTPs and $0.25 \mathrm{mM}$ of each primer. PCR products were purified with Qiaquick Gel Extraction Kit as described above and cloned into E.coli One Shot ${ }^{\circledR}$ competent cells using the pCR 4-TOPO TA cloning kit for sequencing (Invitrogen) following the manufacturer's instructions. Sanger sequencing was performed on an ABI 3700 system using the BigDye kit v. 3.1. Sequences $(\mathrm{n}=10)$ were checked for quality and trimmed using the program $\mathrm{ABI}$ sequence scanner version 1.0, subsequently aligned to known sequences using BLAST (Altschul et al. 1990), and analyzed for potential chimeric sequences using Mallard (Ashelford et al. 2006). The sequences of the amplification products were all perfect matches (100\% identity) to existing freshwater LD12 sequences (e.g. GenBank accession number Z99997).

\section{CARD-FISH}

Abundance of LD12 was determined by CARDFISH for 8 time points covering 2 abundance gradients around the LD12 abundance maxima in spring and autumn. The chosen time points were also characterized by variation in phytoplankton composition. For CARD-FISH, $10 \mathrm{ml}$ aliquots were collected and fixed with ethanol (50\% final concentration) for 1 to $24 \mathrm{~h}$ at $4^{\circ} \mathrm{C}$. The archived samples were subsequently filtered onto $0.2 \mu \mathrm{m}$ pore size, $25 \mathrm{~mm}$ diameter GTTP polycarbonate filters (Millipore) and stored at $-20^{\circ} \mathrm{C}$ (Sekar et al. 2003). CARD-FISH was performed according to Sekar et al. 2003 with slight modifications for LD12 (Salcher et al. 2013). The frac- 
tion of objects detected by probes and DAPI stained objects was determined by epifluorescence microscopy (Leica DMRD). For each sample at least 10 pictures, as well for the probe as for DAPI were taken and analyzed using the ImageJ cell counter plugin (http://rsbweb.nih.gov). A minimum of 1000 DAPI stained cells was counted for each sample.

\section{4 pyrosequencing}

Each DNA sample was amplified in triplicate $20 \mu \mathrm{l}$ reactions with bacterial primers $341 \mathrm{~F}-805 \mathrm{R}$ using the following conditions: $95^{\circ} \mathrm{C}$ for $5 \mathrm{~min}$, followed by 25 cycles of denaturation at $95^{\circ} \mathrm{C}$ for $40 \mathrm{~s}$, annealing at $53^{\circ} \mathrm{C}$ for $40 \mathrm{~s}$ and extension at $72^{\circ} \mathrm{C}$ for $60 \mathrm{~s}$ followed by final $7 \mathrm{~min}$ extension at $72^{\circ} \mathrm{C}$. Individual PCR reactions contained 1 to $10 \mathrm{ng}$ of target DNA, 1nM Phusion HF buffer, 0.02 nM Phusion Enzyme DNA polymerase (Finnzyme), dNTPs at $0.2 \mathrm{mM}$ each and $0.5 \mathrm{mM}$ of each primer. The $5^{\prime}$ end of primer 805R was linked to a sample-specific 5-nucleotide DNA barcode and 454 FLX amplicon adapter $A_{\text {; }}$ whereas the 5' end of primer $341 \mathrm{~F}$ was linked to FLX amplicon adaptor B (Table S3 in the Supplement). Pooled PCR reactions from each sample were quantified by electrophoretic separation on a $2 \%$ agarose gel, followed by ethidium bromide staining and quantification by UV transillumination and compared to a Low DNA Mass Ladder (Invitrogen). Imaging and image analysis were performed using a Spectronics variable-intensity UV source with a diffuser plate, a cooled 12-bit CCD camera (CoolSNAPPro cf) and Gel-Pro Analyser software version 3.1 (Media Cybernetics). PCR products of equal DNA concentration from each sample were combined and further purified by gel purification (Qiaquick Gel Extraction Kit) for pyrosequencing from FLX adaptor A on a Roche GS FLX system at the Centre for Metagenomic Sequence Analysis at the Royal Institute of Technology, Stockholm, Sweden. The 454 sequence run has been deposited in the NCBI Short Read Archive under accession number SRP007933 (Eiler et al. 2012).

\section{Taxonomic identification}

We recovered 118912 sequence reads after removing those shorter than $200 \mathrm{bp}$ or containing ambiguous bases as well as reads with mismatches to the primers or barcodes by performing the trim.seq command in mothur (Schloss et al. 2009).
From these sequences, 19638 non-redundant 454 sequences were extracted and cross-compared against a local freshwater bacterial sequence database including almost 12000 sequence entries (Newton et al. 2011). This database contains sequences generated by traditional Sanger technology from epilimnetic water samples in various lakes from around the world and follows a hierarchical naming structure (phylum/lineage/clade/tribe) illustrating the relationships between sequences using a robust phylogenetic framework. The tribe represents the most refined taxonomic group of this freshwater bacterioplankton taxonomy. It is defined as a group of sequences clustering as a monophyletic branch of a phylogenetic tree, but requires each sequence to have $\geq 97 \%$ sequence identity to another sequence of that branch. In this freshwater taxonomy, tribe LD12 belongs to the alphaproteobacterial subphylum, alIV lineage and alIV-A clade (Newton et al. 2011).

Each non-redundant 454 sequence was BLASTN searched against this freshwater bacterial database with default parameters and inherited the taxonomic annotation (down to tribe level) of the best scoring hit, fulfilling the criteria of at least $95 \%$ identity over a minimum alignment length of $200 \mathrm{bp}$. If no such hit was found, the sequence was classified as 'no match' (Andersson et al. 2010). Denoising the 454 sequences using Amplicon Noise as previously described (Eiler et al. 2013), did not affect the calculated LD12/Bacteria 454-read ratio (see Fig S1 in the Supplement)

To test the impact of plastid sequences, we identified chloroplast sequences by using the Bayesian classifier (Wang et al. 2007) and the rdp6 database implemented in mothur (Table S3). Statistical analyses were performed with and without plastid sequences as outlined below. Since results were highly similar we only reported the results from the noncorrected dataset to allow comparison with the qPCR results.

\section{Data analyses}

Spearman rank correlation analyses among tribes was performed in PAST (Hammer et al. 2001). Multivariate statistical analyses were performed in Simca-P+ version 11.0 (Umetrics; Wold et al. 2001). Prior to analysis, environmental variables were logtransformed, where appropriate, to obtain normality. The relative abundance of LD12 obtained by 454 sequencing and qPCR was used to develop a predictive model that described temporal variability in LD12 based on partial least squares to latent 
structure (PLS) analysis. The model identified linear regressions of the LD12 abundance (predicted variable) and the environmental parameter (predictor variables). Only observed variables with significant contribution to the model were included in the PLS analysis (see variance of importance in projection [VIP] plot in Fig. S2 in the Supplement).

No difference for the ecological interpretation of the PLS was observed when comparing the models using the original data set and the data set corrected for chloroplast sequences.

\section{RESULTS}

\section{Seasonal changes of temperature, bacterial abundance and chlorophyll a}

During the study year, Lake Erken experienced the shortest period of ice coverage (February 12 to 24) since beginning of the lake monitoring. Bacterial abundance reached a maximum $\left(1.6 \times 10^{7}\right.$ cells $\left.\mathrm{ml}^{-1}\right)$ concurrent with maximum temperature in July.

The lake was stratified between June and mid August. Oxygen was largely depleted with $0 \%$ oxygen saturation in the deep hypolimnetic waters from end of July to mid August. Toward the end of this period, there was a steep decrease in oxygen at approximately $14 \mathrm{~m}$ depth. Three pronounced chlorophyll maxima were observed in the beginning of March, mid July and beginning of September (Fig 1A, Table S4 in the Supplement).

\section{Seasonal dynamics of LD12}

qPCR revealed that LD12 was present throughout the year and contributed on average $14 \%(n=31$, range 1.8 to $40 \%$ ) to the total bacterial 16S rRNA gene pool in epilimnic water samples or the integrated samples representing the entire mixed water column (Fig 1B). LD12 abundances were highest during summer stratification (July) and late fall (October to December) and were linked to both increasing nitrate and decreasing ammonium concentrations (Table S3 in the Supplement). During these periods, LD12 represented up to $40 \%$ of the total $16 \mathrm{~S}$ rRNA gene pool.
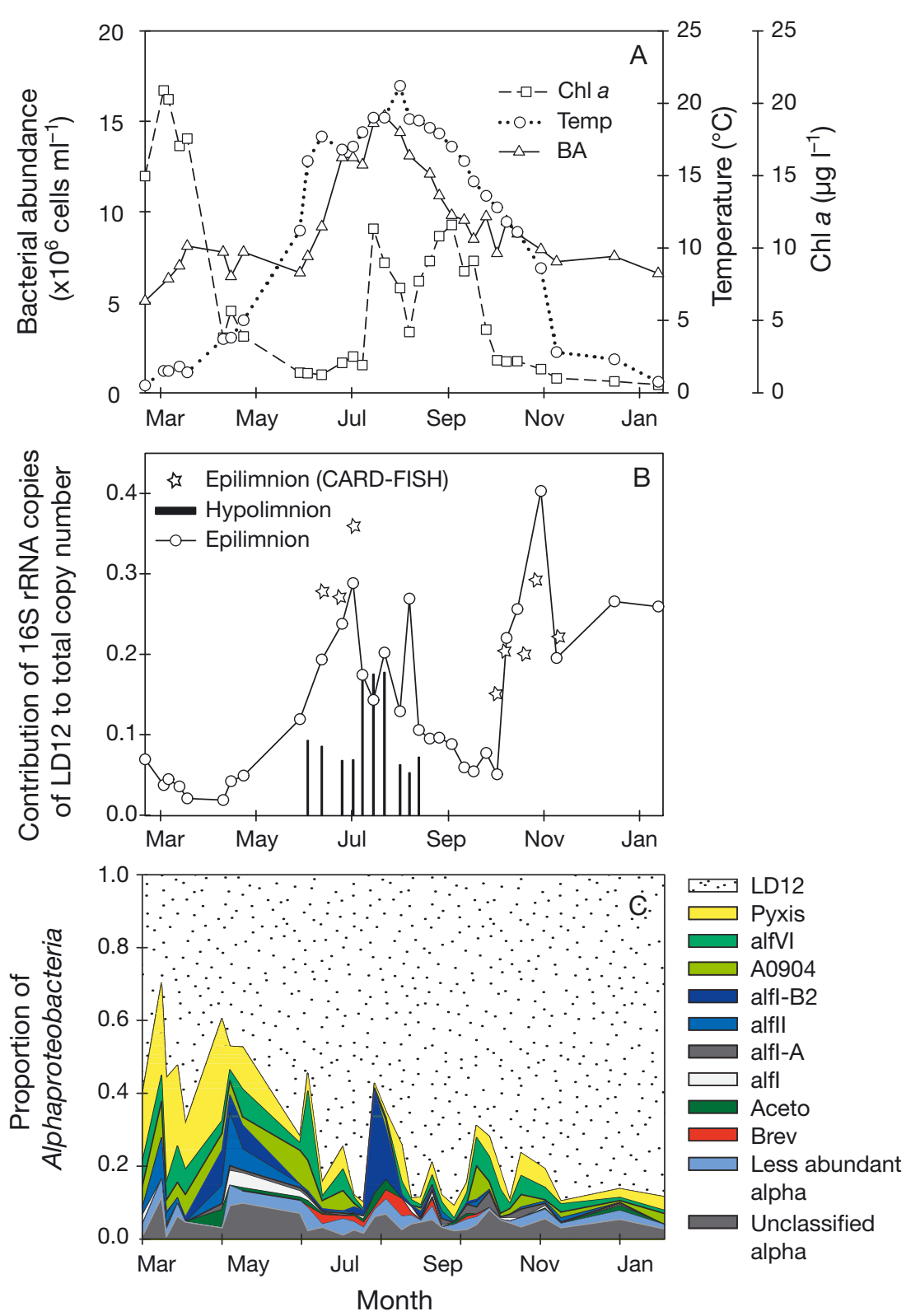

Fig. 1. Seasonal dynamics of environmental factors and LD12 in Lake Erken, Sweden, from February 2008 to January 2009 (n = 32). Epilimnion samples refer to depth-integrated samples obtained from the upper mixed layer during stratification (June to mid August) and from the entire water column for the remainder of the year. (A) Temperature (Temp), chlorophyll a (Chl a) and bacterial abundance (BA); (B) relative LD12 abundance in epilimnion (qPCR and CARD-FISH) and hypolimnion (qPCR); (C) contribution of identified taxonomic groups to the Alphaproteobacteria community based on the relative contribution of taxonomically annotated 454 pyrosequencing reads 
During summer stratification, LD12 was also detected in the hypolimnion (mean $=10 \%$, range 5.2 to $17.7 \%$ ), but other than for one occasion in early July, their relative contribution to the total $16 \mathrm{~S}$ rRNA gene pool was lower than or equal to that in the epilimnetic waters (Fig. 1B). By combining the representation of LD12 in the total 16S rRNA gene pool and the flow cytometry based bacterial cell counts, estimates of absolute LD12 abundance ranged from $1.45 \times$ $10^{5}$ cells ml ${ }^{-1}$ in spring to $3.75 \times 10^{6}$ cells ml $^{-1}$ in summer $\left(\right.$ mean $=1.46 \times 10^{6}$ cells ml $\left.^{-1}\right)$.

CARD-FISH analysis was performed for a subset of 8 samples representing 2 periods of LD12 abundance shifts. LD12 abundances calculated from the direct cell count using CARD-FISH showed similar trends to LD12 abundance derived from qPCR and 454 sequencing (Fig. 1B). While for samples of the first abundance peak in summer CARD-FISH derived abundance displayed slightly higher or identical abundances as the $\mathrm{qPCR}$ derived data (CARD-FISH $\mathrm{n}=8$, average $30 \%$, qPCR average $24 \%$ of the total bacterial community) the abundance in the autumn peak was lower or identical compared to qPCR derived abundance (CARD-FISH average $20 \%$, qPCR average $23 \%$ of the total bacterial community) (Fig. 1B).

LD12 abundance of the sample subset deduced from all 3 methods were tightly rank correlated (454qPCR $\rho=0.55, p=0.17$; qPCR-CARD-FISH $\rho=0.43$, $\mathrm{p}=0.30 ; 454$-CARD-FISH $\rho=0.38, \mathrm{p}=0.36, \mathrm{n}=8$ ). Linear regression analysis between 454 and qPCR derived LD12 abundance including all samples revealed a significant relationship $\left(n=31, R^{2}=0.69\right.$, $\mathrm{p}<0.001)$ corroborating results from a Spearman rank correlation $(\rho=0.89, p<0.001)$.

\section{LD12 diversity and community interactions}

454 pyrosequencing revealed that $10.6 \%$ of the 454 reads were related to Alphaproteobacteria and $6.7 \%$ were classified as LD12. Among these LD12 reads, $81 \%$ belonged to a single sequence or ribotype. More than $95 \%$ of the LD12 reads were at least $99 \%$ identical to a single pre-existing LD12 entry in the freshwater database or GenBank (accession number Z99997). From the remaining sequences assigned to LD12, more than $99 \%$ were at least $99 \%$ identical to another existing sequence affiliated with the LD12 tribe.

Cross-correlation analyses (Spearman rank correlation) revealed co-occurrence patterns of LD12 with multiple bacterial tribes and broader groups (phyla) identified in the 454 dataset (Table S5 in the Supplement).
LD12 was clearly the dominant Alphaproteobacteria tribe, contributing on average $72 \%$ to this class (Fig. 1C). The highest contribution of LD12 to the Alphaproteobacteria community (91\%) was observed in early September and the tribe remained dominant for the rest of the year. In spring, the relative contribution of LD12 to the total alphaproteobacterial 16S rRNA sequences dropped to approximately $30 \%$. With the onset of the spring bloom, LD12 was replaced by a diverse alphaproteobacterial community consisting of populations affiliated with the lineages alf-II, alf-VI as well as tribes Pyxis and alfI-B2. Tribe Pyxis (Sphingopyxis) contributed significantly to Alphaproteobacteria in most spring samples and contributed up to $28 \%$ of the Alphaproteobacteria reads in March and April while remaining rare during other times of the year $(4 \%$ average of the Alphaproteobacteria 16S rRNA reads during May to February). Tribe alfI-B2, within the Rhizobiales, contributed up to $10 \%$ of the Alphaproteobacteria $16 \mathrm{~S}$ rRNA reads and was most abundant in early March, end of May, and mid-September. This tribe was also detected throughout the study period, but at low relative abundance. Such pronounced dynamics in relative abundance were also observed in tribe A0904, which made up $28 \%$ of the Alphaproteobacteria 16S rRNA reads in July, while it was rarely detected during the rest of the year. Reads grouping with the family Acetobacteraceae and tribe Brev were present in low numbers throughout the study period and contributed at most $4 \%$ to the total Alphaproteobacteria.

\section{Environmental drivers of LD12}

The relationship between LD12 abundance and both intrinsic and extrinsic environmental parameters was examined using multivariate PLS. Seasonal partitioning of the samples of the 4 seasons was evident by the score plot of the PLS analysis (Fig. 2A). Seasonal changes in lake water properties are shown in Table S3. Variables that provided little to no explanation in the model were excluded from further analysis. The resulting model provided a satisfactory goodness of fit $\left(\mathrm{R}^{2}=0.60\right)$ and goodness of prediction $\left(\mathrm{Q}^{2}=0.50\right.$; Fig. 2). As revealed by PLS analysis, LD12 abundance was strongly positively correlated to high bacterial abundance and high concentrations of dissolved nutrients such as phosphate (soluble reactive phosphorus [SRP]), ammonium, nitrate and silica. Also periods of high water transparency (Secchi depth) appeared to create favorable conditions for 

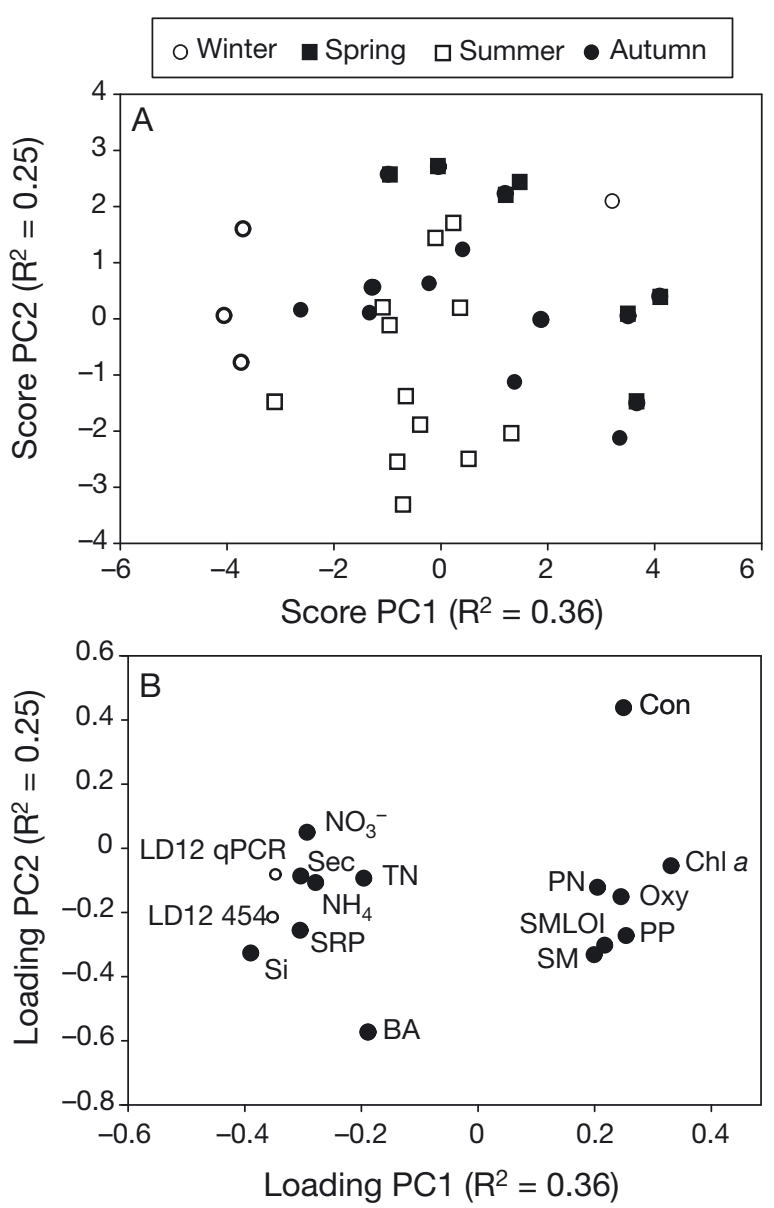

Fig. 2. (A) Partial least squares to latent structure (PLS) based score plot mapping the individual samples $(\mathrm{n}=31)$ illustrating the seasonality in Lake Erken. (B) PLS based loading plot showing the relationships between LD12 relative abundance and environmental parameters: $(\boldsymbol{O})$ predictor variables, i.e. environmental parameters (TN: total nitrogen; Sec: Secchi depth; SRP: soluble reactive phosphorus; BA: bacterial abundance; PN: particulate nitrogen; Si: silica; Con: conductivity; SM: suspended matter; SMLOI: suspended matter loss on ignition; PP: particulate phosphorus; Oxy: oxygen; Chl a: chlorophyll a); (O) the response variable, i.e. relative LD12 abundance, identified by qPCR and 454 sequencing

LD12, whereas high chlorophyll a content and high levels of nutrients in the particulate fraction (particulate phosphorus, particulate nitrogen, suspended matter and loss on ignition) were characteristic features of samples with low representation of LD12 in the bacterioplankton (Fig. 2B).

LD12 abundance, estimated by either qPCR or relative ribotype representation observed in the 454-pyrosequencing-enabled bacterial 16S rRNA gene survey, was highly correlated and similarly related to environmental state variables as indicated by the close proximity of the 2 variables in the PLS loading plot (Fig. 2B). This was also confirmed by a regression analysis $\left(\mathrm{R}^{2}=0.69, \mathrm{p}<0.001\right)$ indicating that quantification of LD12 using these methods do correspond. Still, there was a major systematic difference between the 2 methods, where estimated relative abundances from qPCR were more than twice as high as abundances derived from 454 pyrosequencing. This was also seen in the regression analysis, where the slope was 2.05 with a standard error of 0.25 . This may indicate preferential amplification of some other abundant bacterial populations that becomes more pronounced in the end-point PCR amplification used for the 454 pyrosequencing, or in the 454 pyrosequencing reaction. Since previous data on the prevalence and abundance of LD12 in bacterioplankton are based exclusively on such mixed-template bacterial-level 16S rRNA amplicon surveys, their numerical significance in freshwater ecosystems may have been underestimated.

\section{DISCUSSION}

Members of the SAR11 clade are often dominant in marine bacterial communities and can contribute up to $50 \%$ of the total bacterioplankton (Morris et al. 2002, Carlson et al. 2009, Eiler et al. 2009, Giebel et al. 2011). Accordingly, members of the SAR11 clade have been intensively investigated with regards to their distribution patterns, physiology, and genomic characteristics (Malmstrom et al. 2004, 2007, Giovannoni et al. 2005a,b, Alonso \& Pernthaler 2006, Wilhelm et al. 2007, Tripp et al. 2009, Schwalbach et al. 2010, Grote et al. 2012). In the present study we show that LD12, a freshwater sibling to the marine SAR11 lineage, can be equally numerous in freshwater bacterioplankton communities and can contribute up to $40 \%$ of the total pool of bacterial 16S rRNA genes. qPCR and 454 pyrosequencing of bacterial 16S rRNA genes revealed that LD12 was not only present throughout the year, but also uncovered strong temporal dynamics in relative and estimated absolute abundances (Fig. 1B). In support of this, comparative analyses by CARD-FISH revealed a similar LD12 abundance pattern.

Occasionally (in early spring) LD12 contributed less than $2 \%$ of the total bacterial 16S rRNA genes, which highlights the need for temporally resolved characterization of lake bacterioplankton communities in order to identify the key players in these strongly seasonal aquatic ecosystems.

The numerical importance of LD12 in Lake Erken is comparable to recent observations from central 
European lakes (Salcher et al. 2011a), and thus extend these findings of LD12 as a numerically significant lake bacterioplankton community member to also include dimictic lakes at high latitudes. Strong temporal variation in LD12 abundance over seasonal timescales, as observed in Lake Erken, was also evident in 3 Austrian and Swiss lakes (Salcher et al. 2011a). This implies that pronounced population dynamics may be a characteristic feature of this bacterial group, at least in lakes that undergo seasonal change in stratification patterns, water chemistry, and other potentially structuring environmental factors. Strong temporal dynamics have also been reported for SAR11 in marine systems, which seem to be coupled to the seasonality of physicochemical features in these environments (Morris \& Vergin 2005, Campbell et al. 2009, Carlson et al. 2009, Eiler et al. 2009, Simonato et al. 2010).

Moreover, LD12 in Lake Erken feature a minor but significant habitat preference for the photic zone (Fig. 1B) pointing to a preference of higher irradiance (Fig. 2B). This is in agreement with a vertical profile of LD12 abundance in Lake Zürich (Salcher et al. 2011b) and mirrors the characteristic depth distribution of marine SAR11 subclass Ia (Suzuki et al. 2001, Carlson et al. 2009). It also agrees with the recent detection of LD12-proteorhodopsins and implied photoheterotrophic potential (Martinez-Garcia et al. 2012). Both the marine and freshwater SAR11 have been reported to exhibit an oligotrophic life style (Giovannoni et al. 2005a, Salcher et al. 2011a). In marine oligotrophic environments, low levels of substrates have been found to favor SAR11 subgroups Ia and Ib, as they, compared to other bacterioplankton, are more successful in acquiring low concentrations of labile substrates such as amino acids, sugars, aromatic monomers, and DMSP (Malmstrom et al. 2004, Mary et al. 2006). In earlier surveys, LD12 abundance and activity appears to be linked to low phosphate concentrations, and ecophysiological single cell assays for substrate specificity have demonstrated that they efficiently use organic substrates at concentrations as low as $1 \mathrm{nM}$ (Salcher et al. 2011a, 2013). These uptake assays have also revealed a preference for amino acids of the glutamate family and in particular glutamine, which is known to be enriched in diatom cell plasma (Hecky et al. 1973). Our observations that LD12 comprises a higher proportion of the bacterial community under low productivity conditions characterized by high water transparency and low phytoplankton biomass, corroborate the previously suggested oligotrophic lifestyle of LD12.
Still, with regards to other environmental variables such as the concentration of free inorganic nutrients, contrasting patterns are observed. Whereas the representation of LD12 in the Lake Erken bacterioplankton community was highest during periods of high phosphate, nitrate, and ammonium levels, Salcher et al. (2011a) reported a negative correlation between LD12 abundance and nitrate as well as phosphate concentration. Such conflicting results have also been observed for marine SAR11, with reports of both positive (Teira et al. 2009) and negative (Eiler et al. 2009) correlations to nitrate and ammonium levels. This may suggest ecological differentiation within the SAR11/LD12 group, but could also indicate interactive effects between free nutrient levels and other environmental factors that may differ between geographic regions and individual lakes. Other observations that may reflect such habitat- or population-specific differences in SAR11/LD12 ecology include the negative correlation between LD12 and the amount of particulate matter in Lake Erken (Fig. 2B). This pattern is different from the positive relationship observed between particulate carbon, nitrogen, phosphate and silica and the relative abundance of marine SAR11 (Eiler et al. 2009). Another observation in support of habitat-specific ecological differentiation within the SAR11 lineage is the strong temperature control of LD12 in Austrian and Swiss lakes (Salcher et al. 2011a); although temperature seemed not to be a strong influencing factor in the northern lake studied here. In spite of the potential contrasting patterns resulting from contrasting study design and detection methods (cell vs. DNA based), these apparent differences in distribution patterns call for further studies of the genetic and ecological divergence within the global LD12 community, particularly for spatially separated populations.

For the marine SAR11 clade, spatial and temporal separation of subclades have been reported in the Sargasso Sea (Morris \& Vergin 2005, Carlson et al. 2009) and in the Global Ocean Survey (Rusch et al. 2007), providing additional support for ecological diversification. Such temporal or spatial separation of subpopulations was not evident for the local LD12 population in Lake Erken, since both the epilimnetic and hypolimnetic population featured a single dominant ribotype $(99.5 \%$ average $16 \mathrm{~S}$ rRNA identity using $200 \mathrm{bp}$ of the 16Sr RNA) throughout the year. The hypolimnetic LD12 population even persisted at stable relative abundance over a month long period of gradual oxygen depletion, suggesting either considerable functional versatility or tolerance to this drastic change in the local environment (e.g. hyp- 
oxia) or a more recent ecological diversification of LD12 that is not detected in the rather slowly evolving 16S rRNA gene. Previous phylogenetic analyses of LD12 from a global 16S rRNA database do support microdiversification and hence the existence of ecologically and genetically diversified LD12 populations (Logares et al. 2010). A more recent phylogeographic analysis suggests that such subclusters (supported bootstrap values $>50 \%$ ) were typically restricted to single lakes, but several clusters could occasionally also be detected within a single system (Lake Zürich; Salcher et al. 2011a).

The highest Alphaproteobacteria diversity cooccurred with the lowest total bacterial abundance in spring. Members belonging to the alphaproteobacterial lineages alf-II and alf-VI, and tribes Pyxis and alfI-B2 contributed substantially to this spring alphaproteobacterial community. Members of lineages alf-II (former Brevundimonas/Caulobacter) and tribe Pyxis (overlapping with genus Sphingopyxis) have previously been found in association with Cyanobacteria (Berg et al. 2009). Simultaneous with the decrease of LD12 abundance during the cyanobacterial bloom, the tribe A0904 peaked with a contribution of up to $30 \%$ to the alphaproteobacterial community (Fig. 1C). This tribe was previously detected during cyanobacterial blooms in Swedish lakes (Eiler \& Bertilsson 2004) and has also been found to be physically attached to cyanobacterial colonies (Eiler et al. 2006).

Positive correlations found between LD12 and several other abundant freshwater bacterioplankton groups may result from shared ecological features with populations being controlled by the same regulatory factors, but could also result from physical linkages or functional interdependencies (Table S5; Eiler et al. 2012). For instance the reduced cell size of LD12 and other freshwater bacteria might enhance the capacity to assimilate substrates and nutrients under resource-limited conditions due to increased surface to volume ratio (Koch 1996, Young 2006, Salcher et al. 2011a). Such an oligotroph or high-affinity lifestyle has also been implied for marine SAR11, as representative genomes feature an abundance of genes and proteins associated with nutrient and organic substrate uptake (Giovannoni et al. 2005a, Sowell et al. 2009). Another competitive advantage of small cell size relates to predation susceptibility. Though not explicitly addressed in the present study, size-structured predation by microeukaryotes may influence bacterial community composition, where small cell size may also confer a major competitive advantage compared to larger bacteria (Pernthaler 2005, Young
2006). In support of this, the relative abundance of LD12 was at the annual maximum during a period of high zooplankton abundance (Beier 2010).

In conclusion, the present study has demonstrated that LD12 can be abundant in lake bacterioplankton communities and that their contribution to the total bacterioplankton community can vary dramatically over seasonal timescales. At the same time, a single ribotype appears to dominate the LD12 community in the studied lake, implying that there is limited diversification within the tribe, at least on the local scale. The slowly evolving 16S rRNA gene is still a fairly blunt tool to resolve ecologically congruent groups. Future research is still needed to advance our knowledge about LD12 ecology, specifically to study this abundant freshwater tribe by means of proteincoding marker genes which may hold the potential to better resolve ecologically distinct LD12 populations. Access to genome-level characteristics of geographically separated LD12 populations could also inform us about the genetic background of ecological differentiation. Ideally, this should be combined with multi-annual surveys at higher sampling frequency to detect phenology and more precisely identify the environmental drivers that control these elusive but abundant freshwater Alphaproteobacteria.

Acknowledgements. We thank the entire staff at the Lake Erken Field Station for logistic support, sampling assistance and access to water quality monitoring data. We also thank Kevin Bakker and 5 anonymous reviewers for valuable comments on the manuscript. The work was funded by the Swedish Research Council (grant to S.B.) with additional support from the Malmén and Olsson-Borg foundations (grants to F.H.). Pyrosequencing was partially funded by the Centre for Metagenomic Sequence Analysis at the Swedish Royal Institute of Technology funded by the Knut and Alice Wallenberg foundation.

\section{LITERATURE CITED}

Alonso C, Pernthaler J (2006) Roseobacter and SAR11 dominate microbial glucose uptake in coastal North Sea waters. Environ Microbiol 8:2022-2030

> Alonso-Sáez L, Arístegui J, Pinhassi J, Gómez-Consarnau L and others (2007) Bacterial assemblage structure and carbon metabolism along a productivity gradient in the NE Atlantic Ocean. Aquat Microb Ecol 46:43-53

Altschul SF, Gish W, Miller W, Myers EW, Lipman DJ (1990) Basic local alignment search tool. J Mol Biol 215:403-410

> Andersson AF, Riemann L, Bertilsson S (2010) Pyrosequencing reveals contrasting seasonal dynamics of taxa within Baltic Sea bacterioplankton communities. ISME J 4: 171-181

> Ashelford KE, Chuzhanova NA, Fry JC, Jones AJ, Weightman AJ (2006) New screening software shows that most 
recent large 16S rRNA gene clone libraries contain chimeras. Appl Environ Microbiol 72:5734-5741

Bahr M, Hobbie JE, Sogin ML (1996) Bacterial diversity in an arctic lake: a freshwater SAR11 cluster. Aquat Microb Ecol 11:271-277

Beier S (2010) Bacterial degradation and use of chitin in aquatic habitats. Digital comprehensive summaries of Uppsala dissertations from the Faculty of Science and Technology, Uppsala University

> Berg KA, Lyra C, Sivonen K, Paulin L, Suomalainen S, Tuomi P, Rapala J (2009) High diversity of cultivable heterotrophic bacteria in association with cyanobacterial water blooms. ISME J 3:314-325

Campbell BJ, Yu L, Straza TRA, Kirchman DL (2009) Temporal changes in bacterial rRNA and rRNA genes in Delaware (USA) coastal waters. Aquat Microb Ecol 57: 123-135

> Carlson CA, Morris R, Parsons R, Treusch AH, Giovannoni SJ, Vergin K (2009) Seasonal dynamics of SAR11 populations in the euphotic and mesopelagic zones of the northwestern Sargasso Sea. ISME J 3:283-295

del Giorgio PA, Bird DF, Prairie YT, Planas D (1996) Flow cytometric determination of bacterial abundance in lake plankton using the green nucleic acid stain SYTO 13. Limnol Oceanogr 41:783-789

Eiler A, Bertilsson S (2004) Composition of freshwater bacterial communities associated with cyanobacterial blooms in four Swedish lakes. Environ Microbiol 6:1228-1243

Eiler A, Olsson JA, Bertilsson S (2006) Diurnal variations in the auto- and heterotrophic activity of cyanobacterial phycospheres (Gloeotrichia echinulata) and the identity of attached bacteria. Freshw Biol 51:298-311

- Eiler A, Hayakawa DH, Church MJ, Karl DM, Rapp MS (2009) Dynamics of the SAR11 bacterioplankton lineage in relation to environmental conditions in the oligotrophic North Pacific subtropical gyre. Environ Microbiol 11:2291-2300

> Eiler A, Heinrich F, Bertilsson S (2012) Coherent dynamics and association networks among lake bacterioplankton taxa. ISME J 6:330-342

- Eiler A, Drakare S, Bertilsson S, Pernthaler J and others (2013) Unveiling distribution patterns of freshwater phytoplankton by a next generation sequencing based approach. PLoS ONE 8:e53516

Giebel HA, Kalhoefer D, Lemke A, Thole S, Gahl-Janssen R, Simon M, Brinkhoff T (2011) Distribution of Roseobacter RCA and SAR11 lineages in the North Sea and characteristics of an abundant RCA isolate. ISME J 5:8-19

Giovannoni SJ, Sting U (2005) Molecular diversity and ecology of microbial plankton. Nature 437:343-348

> Giovannoni SJ, Britschgi TB, Moyer LC, Field KG (1990) Genetic diversity in Sargasso Sea bacterioplankton. Nature 345:60-63

Giovannoni SJ, Tripp HJ, Givan S, Podar M and others (2005a) Genome streamlining in a cosmopolitan oceanic bacterium. Science 309:1242-1245

Giovannoni SJ, Bibbs L, Cho JC, Stapels MD and others (2005b) Proteorhodopsin in the ubiquitous marine bacterium SAR11. Nature 438:82-85

> Glöckner FO, Zaichikov E, Belkova N, Denissova L, Pernthaler J, Pernthaler A, Amann R (2000) Comparative 16S rRNA analysis of lake bacterioplankton reveals globally distributed phylogenetic clusters including an abundant group of Actinobacteria. Appl Environ Microbiol 66: 5053-5065
Grote J, Thrash JC, Huggett MJ, Landry ZC, Carini P, Giovannoni SJ, Rappe MS (2012) Streamlining and core genome conservation among highly divergent members of the SAR11 clade. mBio 3:e00252-12

Hammer Ø, Harper DAT, Ryan PD (2001) PAST: paleontological statistics software package for education and data analysis. Palaeontol Electronica 4:4-9

- Hecky RF, Mopper K, Kilham P, Degens ET (1973) The amino acid and sugar composition of diatom cell walls. Mar Biol 19:323-331

Herlemann DPR, Labrenz M, Jürgens K, Bertilsson S, Waniek JJ, Andersson AF (2011) Transitions in bacterial communities along the $2000 \mathrm{~km}$ salinity gradient of the Baltic Sea. ISME J 5:1571-1579

> Hiorns WD, Methé BA, Nierzwicki-Bauer SA, Zehr JP (1997) Bacterial diversity in Adirondack mountain lakes as revealed by $16 \mathrm{~S}$ rRNA gene sequences. Appl Environ Microbiol 63:2957-2960

Joint I (2008) Unravelling the enigma of SAR11. ISME J 2: $455-456$

Koch AL (1996) What size should a bacterium be? A question of scale. Annu Rev Microbiol 50:317-348

Lane DJ (1991) 16S/23S rRNA sequencing. In: Stackebrandt E, Goodfellow M (eds) Nucleic acid techniques in bacterial systematics. John Wiley \& Sons, New York, NY

Lindström ES, Leskinen E (2002) Do neighboring lakes share common taxa of bacterioplankton? Comparison of 16S rDNA fingerprints and sequences from three geographic regions. Microb Ecol 44:1-9

Lindström ES, Kamst-van Agterveld MP, Zwart G (2005) Distribution of typical freshwater bacterial groups is associated with $\mathrm{pH}$, temperature and lake water retention time. Appl Environ Microbiol 71:8201-8206

> Logares R, Bråte J, Heinrich F, Shalchian-Tabrizi K, Bertilsson $S$ (2010) Infrequent transitions between saline and fresh waters in one of the most abundant microbial lineages (SAR11). Mol Biol Evol 27:347-357

Malmstrom RR, Kiene RP, Cottrell MT, Kirchman DL (2004) Contribution of SAR11 bacteria to dissolved dimethylsulfoniopropionate and amino acid uptake in the North Atlantic Ocean. Appl Environ Microbiol 70:4129-4135

> Malmstrom RR, Straza TRA, Cottrell MT, Kirchman DL (2007) Diversity, abundance and biomass production of bacterial groups in the western Arctic Ocean. Aquat Microb Ecol 47:45-55

- Martinez-Garcia M, Swan BK, Poulton NJ, Gomez ML, Masland D, Sieracki ME, Stepanauskas R (2012) Highthroughput single-cell sequencing identifies photoheterotrophs and chemoautotrophs in freshwater bacterioplankton. ISME J 6:113-123

- Mary I, Heywood JL, Fuchs BM, Amann R, Tarran GA, Burkill PH, Zubkov MV (2006) SAR11 dominance among metabolically active low nucleic acid bacterioplankton in surface waters along an Atlantic meridional transect. Aquat Microb Ecol 45:107-113

Methé BA, Zehr JP (1999) Diversity of bacterial communities in Adirondack lakes: Do species assemblages reflect lake water chemistry? Hydrobiologia 401:77-96

> Morris RM, Vergin KL (2005) Temporal and spatial response of bacterioplankton lineages to annual convective overturn at the Bermuda Atlantic Time-series Study site. Limnol Oceanogr 50:1687-1696

> Morris RM, Rappé MS, Connon SA, Vergin KL, Siebold WA, Carlson CA, Giovannoni S (2002) SAR11 clade domina- 
tes ocean surface bacterioplankton communities. Nature 420:806-810

Newton RJ, Jones SE, Eiler A, McMahon KD, Bertilsson S (2011) A guide to the natural history of freshwater lake bacteria. Microbiol Mol Biol Rev 75:14-49

Pernthaler J (2005) Predation on prokaryotes in the water column and its ecological implications. Nat Rev Microbiol 3:537-546

Pettersson K (1990) The spring development of phytoplankton in Lake Erken: species composition, biomass, primary production and nutrient conditions - a review. Hydrobiologia 191:9-14

Pettersson K, Grust K, Weyhenmeyer G, Blenckner T (2003) Seasonality of chlorophyll and nutrients in Lake Erkeneffects of weather conditions. Hydrobiologia 506-509: $75-81$

Rusch DB, Halpern AL, Sutton G, Heidelberg KB and others (2007) The Sorcerer II Global Ocean Sampling expedition: northwest Atlantic through eastern tropical Pacific. PLoS Biol 5:e77

Salcher MM, Pernthaler J, Posch T (2011a) Seasonal bloom dynamics and ecophysiology of the freshwater sister clade of SAR11 bacteria 'that rule the waves' (LD12). ISME J 5:1242-1252

Salcher MM, Pernthaler J, Frater N, Posch T (2011b) Vertical and longitudinal distribution patterns of different bacterioplankton populations in a canyon-shaped, deep prealpine lake. Limnol Oceanogr 56:2027-2039

Salcher MM, Posch T, Pernthaler J (2013) In situ substrate preferences of abundant bacterioplankton populations in a prealpine freshwater lake. ISME J 7:896-907

Schloss PD, Westcott SL, Ryabin T, Hall JR and others (2009) Introducing mothur: open-source, platform-independent, community-supported software for describing and comparing microbial communities. Appl Environ Microbiol 75:7537-7541

Schwalbach MS, Tripp HJ, Steindler L, Smith DP, Giovannoni SJ (2010) The presence of the glycolysis operon in SAR11 genomes is positively correlated with ocean productivity. Environ Microbiol 12:490-500

Sekar R, Pernthaler A, Pernthaler J, Warnecke F, Posch T, Aman R (2003) An improved protocol for quantification of freshwater Actinobacteria by fluorecence in situ hybridization. Appl Environ Microbiol 69:2928-2935

Simonato F, Gómez-Pereira PR, Fuchs BM, Amann R (2010)

Editorial responsibility: Jed Fuhrman,

Los Angeles, California, USA
Bacterioplankton diversity and community composition in the southern lagoon of Venice. Syst Appl Microbiol 33:128-138

Sowell SM, Wilhelm LJ, Norbeck AD, Lipton MS and others (2009) Transport functions dominate the SAR11 metaproteome at low-nutrient extremes in the Sargasso Sea. ISME J 3:93-105

> Suzuki MT, Preston CM, Chavez FP, DeLong EF (2001) Quantitative mapping of bacterioplankton populations in seawater: field tests across an upwelling plume in Monterey Bay. Aquat Microb Ecol 24:117-127

- Teira E, Martínez-García S, Lønborg C, Álvarez-Salgado XA (2009) Growth rates of different phylogenetic bacterioplankton groups in a coastal upwelling system. Environ Microbiol Rep 1:545-554

Tripp HJ, Michael SS, Michelle MM, Joshua BK, Ronald RB, Stephen JG (2009) Unique glycine-activated riboswitch linked to glycine-serine auxotrophy in SAR11. Environ Microbiol 11:230-238

> Urbach E, Vergin KL, Young L, Morse A, Larson GL, Giovannoni SJ (2001) Unusual bacterioplankton community structure in ultra-oligotrophic Crater Lake. Limnol Oceanogr 46:557-572

Wang Q, Garrity GM, Tiedje JM, Cole JR (2007) Naïve Bayesian classifier for rapid assignment of rRNA sequences into the new bacterial taxonomy. Appl Environ Microbiol 73:5261-5267

- Wilhelm LJ, Tripp HJ, Givan SA, Smith DP, Giovannoni SJ (2007) Natural variation in SAR11 marine bacterioplankton genomes inferred from metagenomic data. Biol Direct 2:27

Wold S, Sjöström M, Eriksson L (2001) PLS-regression: a basic tool of chemometrics. Chemom Intell Lab Syst 58:109-130

> Young KD (2006) The selective value of bacterial shape. Microbiol Mol Biol Rev 70:660-703

Zwart G, Hiorns WD, Methé BA, van Agterveld MP and others (1998) Nearly identical 16S rRNA sequences recovered from lakes in North America and Europe indicate the existence of clades of globally distributed freshwater bacteria. Syst Appl Microbiol 21:546-556

Zwart G, Crump BC, Kamst-van Agterveld MP, Hagen F, Han SK (2002) Typical freshwater bacteria: an analysis of available 16S rRNA gene sequences from plankton of lakes and rivers. Aquat Microb Ecol 28:141-155

Submitted: February 3, 2012; Accepted: April 25, 2013 Proofs received from author(s): July 9, 2013 